\title{
Flesh or fish? \\ First results of archaeometric research of prehistoric burials from Sakhtysh Ila, Upper Volga region, Russia
}

\author{
Henny Piezonka ', Elena Kostyleva ${ }^{2}$, Mikhail G. Zhilin 3, Maria Dobrovolskaya 3 \\ and Thomas Terberger 4 \\ 1 Ernst Moritz Arndt University Greifswald, Historical Institute, Division of Pre- and Early History, Greifswald, DE \\ piezonkah@uni-greifswald.de \\ 2 Historical Faculty, State University Ivanovo, RU \\ 3 Institute of Archaeology, Russian Academy of Sciences, Moscow, RU \\ 4 Lower Saxony State Office for the Preservation of Monuments, Hanover, DE
}

\begin{abstract}
Graves and their human remains not only shed light on burial customs and social structures of past populations, but also constitute an excellent archive of prehistoric environmental and living conditions. Especially ${ }^{13} \mathrm{C} / 15 \mathrm{~N}$ isotope analysis has recently opened up promising perspectives for reconstructing changes in diet and their social, cultural and economic background. Such investigations have been started on material from the Stone and Early Metal Age hunter-gatherer cemetery of Sakhtysh IIa in the Upper Volga region of Central Russia, where 15 burials associated with the early Lyalovo culture (5th mill. calBC) and 57 graves of the Volosovo culture (4th $-3^{\text {rd }}$ mill. calBC) have been excavated. In this paper, we present new AMS dates and isotopic data from four burials, two from the earlier and two from the later group. The results are discussed against the background of existing dates from Sakhtysh IIa burials and compared with information from other burial sites of Northern Europe.
\end{abstract}

IZVLEČEK - Grobovi in človeški ostanki v njih ne osvetlijo le preteklih pogrebnih praks in družbenih struktur, ampak predstavljajo tudi čudovit arhiv prazgodovinskih okoljskih in življenjskih pogojev. Predvsem analize izotopov ${ }^{13} \mathrm{C}$ in ${ }^{15} \mathrm{~N}$ omogočajo rekonstrukcijo sprememb v prehrani ljudi in nudijo podatke o njihovem družbenem, kulturnem in gospodarskem izvoru. Takšne raziskave smo opravili na materialu iz kamene in zgodnje kovinske dobe na lovsko-nabiralniškem grobišču Sakhtysh IIa na področju zgornje Volge v centralni Rusiji, kjer smo izkopali 15 grobov iz zgodnje kulture Lyalovo (5. tisočletje calBC) in 57 grobov iz kulture Volosovo (4. do 3. tisočletje calBC). V članku predstavljamo nove AMS radiokarbonske datume in izotopske podatke iz štirih grobov, po dva iz zgodnje in pozne faze na najdišču. Rezultate nato primerjamo z že znanimi datumi iz najdišča Sakhtysh IIa in jih primerjamo z datumi iz drugih grobišč v Severni Evropi.

KEY WORDS - Northeastern Europe; Stone and Early Metal Age; hunter-gatherer burials; chronology; diet

Introduction: Prehistoric cemeteries in the Eastern European forest zone

In post-glacial Europe, cemeteries of Stone Age hunter-gather communities are known from Portugal and Brittany in the west, across southern Scandinavia to the eastern Baltic. Well-studied burial sites have enabled archaeologists to draw a detailed picture of the development of funerary rites over space and time and their interdependency with other spheres of life such as settlement, subsistence and economy (Grünberg 2000; Terberger 2010.46-50). In southeastern Europe, two clusters of Mesolithic burial sites have been the focus of long-term multidisciplinary research: the graves of the Lepenski Vir 
culture at the Iron Gates (Bonsall et al. 2004) and the Stone Age cemeteries at the Dnepr rapids in Ukraine (Lillie et al. 2011). In the eastern Baltic, the Latvian cemetery at Zvejnieki has been the focus of international research in recent years (Larsson, Zagorska 2006).

Further northeast in the vast expanses of the Eastern European forest zone, a substantial number of Stone Age cemeteries has been discovered (Oshibkina 2006; Kostyleva, Utkin 2010) (Fig. 1). Due to political constraints of recent history, however, they have remained virtually unknown to the Western European scientific community. This is a sore gap in Pan-European prehistory, as the sites include outstanding complexes such as the uniquely equipped Mesolithic hunter-fisher burials of Oleni Ostrov in Lake Onega and the Late Stone/Early Me-

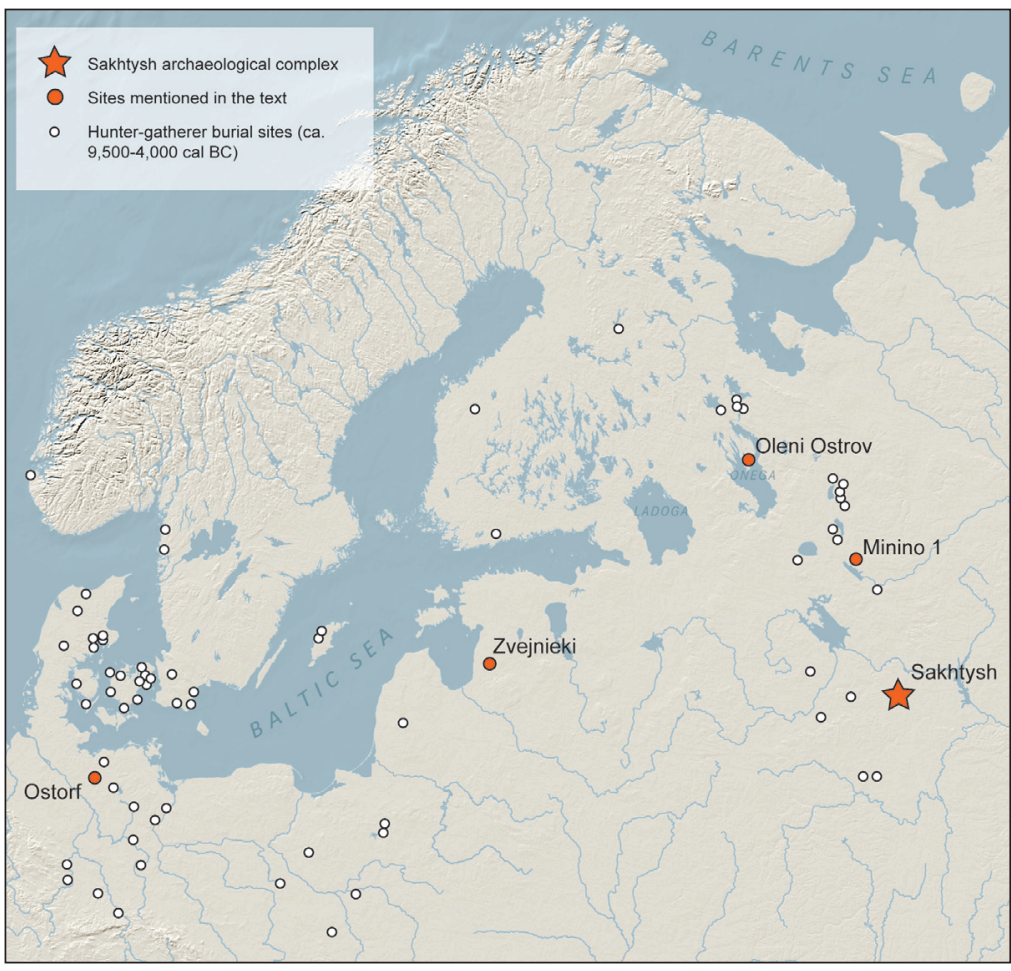

Fig. 1. Holocene hunter-gatherer burial sites in the Northern European forest zone (modified and supplemented after Kostyleva, Utkin 2010.Fig. 124 and Terberger 2010.Fig. 51). tal Age Volosovo amber graves of Central Russia, with hundreds of ornaments made from 'Baltic gold'. The systematic multidisciplinary study of the Eastern European burial sites can contribute valuable insights into local cultural developments, as well as supra-regional contacts and interactions. The use of modern archaeometric analysis of human remains in particular opens up new perspectives: AMS dating enables the construction of a more reliable chronological framework, and stable carbon and nitrogen isotope analysis yields information on diet and at the same time helps to identify possible reservoir effects in the radiocarbon dates.

The present paper introduces the large multi-phase prehistoric cemetery of Sakhtysh IIa in the Upper Volga region of Central Russia. The first results of archaeometric analyses (AMS dating and isotope analysis) of human bone samples of four graves from two different phases are discussed.

\section{Sakhtysh IIa - A Neolithic and Early Metal Age cemetery in the Upper Volga region}

\section{Site context}

The Sakhtysh peat bog is located in Teikovo district of Ivanovo region on the southern slope of the Volga-Klyazma watershed in the Volga-Oka interfluve and is the source of the River Koika (Figs. 1, 2). The area of the peat bog encompasses approx. $50 \mathrm{~km}^{2}$, and until recently a residual lake of about $8 \mathrm{~km}^{2}$ was preserved in its central part. The extension of the gyttia deposits clearly indicates that in ancient times, the lake was much larger.

The first archaeological investigations were conducted in 1930, and a more systematic study of the Sakhtysh archaeological complex was started in 1962 by the Academy of Sciences of the USSR (later the Russian Academy of Sciences) directed by D. A. Krainov, and from 1993 to 2006 by M. G. Zhilin (Kostyleva, Utkin 2010.9).

The archaeological sites detected in the Sakhtysh peat bog are situated on the narrow banks of the old Koika riverbed along a three-kilometre segment from its source (Fig. 2). Five of the sites were of considerable size and have been interpreted as long-term settlements (Sakhtysh I, II, IIa, VII, VIII); six were seasonal stations (Sakhtysh III, IV, IX-XI, XIV), and four were artefact scatters (Sakhtysh V, VI, XII, XIII). Thick accumulations of archaeological material on the larger sites attest to several chronological stages from the Early Mesolithic to the Early Iron Age. The Neolithic in the Russian scientific tradition is defined by the appearance of pottery, not by a transition to a productive economy (Oshibkina 2006). 
In the Volga-Oka region, it starts with the Upper Volga culture at around 6000 calBC and continues with the Middle Neolithic Lyalovo culture evolving at the end of the $6^{\text {th }}$ millennium calBC (Fig. 3). In the Late Neolithic, just after $4000 \mathrm{calBC}$, the transition to the Volosovo culture takes place and this continues to develop into the Early Metal Age.

Apart from the settlement remains, altogether 149 burials from five different sites have come to light in the Sakhtysh archaeological complex, thus accounting for more than $50 \%$ of all prehistoric graves known in the Upper Volga and Volga-Oka interfluve region (Kostyleva, Utkin 2008b; 2010.11). Chronologically, they encompass 20 Neolithic, 128 Late Neolithic/Early Metal Age and one Late Bronze Age interment. While the burial complexes at Sakhtysh II, IIa and VIII have been excavated more or less completely, the graves at Sakhtysh VII were partly destroyed by modern agriculture, and at Sakhtysh I, the main part of a large cemetery is still awaiting investigation.

Within the Sakhtysh complex, Sakhtysh IIa has yielded the largest number of burials. The site occupies an elongated ridge on the left bank of the River Koika (Zaretskaya, Kostyleva 2008.7-8). More than $700 \mathrm{~m}^{2}$ have been archaeologically investigated at this site. Apart from a cultural layer containing finds from the Mesolithic to the Bronze Age, 72 burials of the Lyalovo and Volosovo cultures were discovered. The cemetery of Sakhtysh IIa is distinguished from the other burial sites by a stratification of the graves and the comparatively good preservation of the skeletons. The graves can be grouped into two burial complexes, one cemetery each of the Middle Neolithic Lyalovo culture, and of the Late Neolithic/ Early Metal Age Volosovo culture (Kostyleva, Utkin 2010.37).

\section{The Lyalovo cemetery}

The Middle Neolithic cemetery is represented by 15 inhumation burials, and it is likely that the entire burial field of this phase has been captured (Kostyleva, Utkin 2010.41) (Fig. 4). The association of the burials with the early Lyalovo phase is attested to by stratigraphy: the burial pits have been cut from the lower part of the Lyalovo cultural layer through the underlying Upper Volga cultural layer (Kostyleva, Utkin 2010.246). The later dating of the Late Neolithic/Early Metal Age burials is confirmed by Middle Neolithic graves that were cut by burial pits $(\mathrm{n}=3)$ or partly overlain $(n=3)$ by graves of the Volosovo cemetery. The Lyalovo burial pits had an elongat-

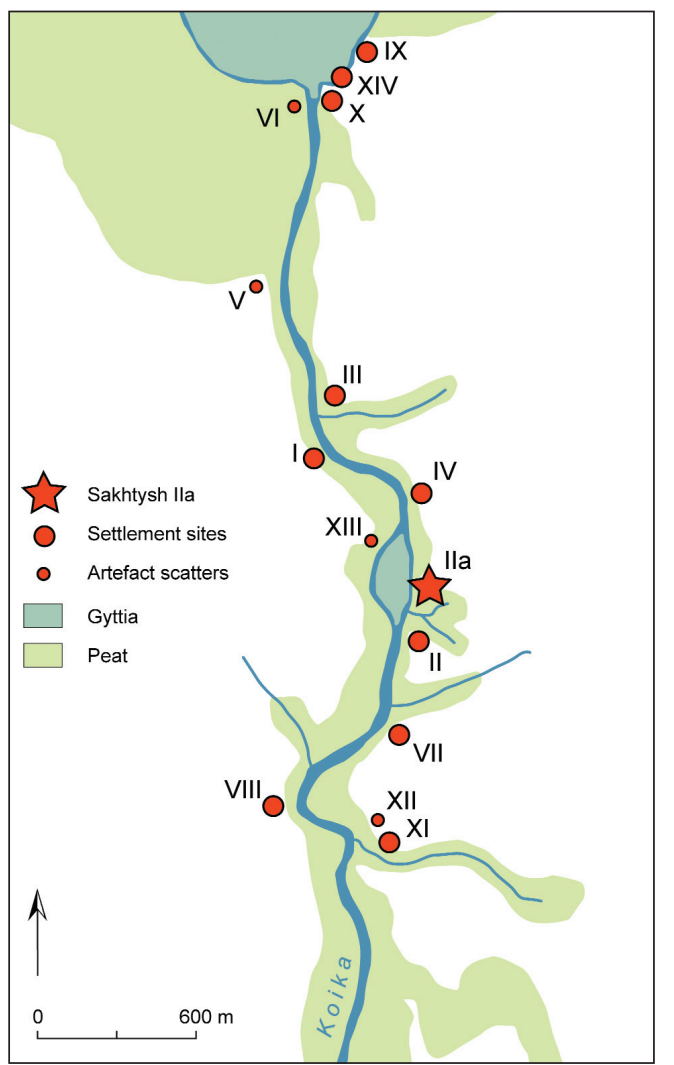

Fig. 2. Archaeological sites in the southern area of the Sakhtysh peat bog (after Kostyleva, Utkin 2010. Fig. 2).

ed sub-rectangular or elliptical shape and ranged in size from $0.9 \times 0.47 \mathrm{~m}$ (small infant burial) to $2.12 \mathrm{x}$ $0.65 \mathrm{~m}$ (large adult burial). The maximum depth of the skeletons below the modern surface was $0.7 \mathrm{~m}$ (Kostyleva, Utkin 2010.37). Most of the burial pits were orientated along a northwest-southeast axis, thus following the long axis of the ridge. In the central part of the cemetery, the graves were arranged in four short rows of two to three burials.

The majority of the graves were individual burials, and only two contained two individuals (no. 59: two children; no. 61: young woman with 2-year-old infant). In eight cases, the deceased lay in an extended supine position; in graves no. 12 and 22 the bodies were positioned face down. Grave no. 11 is the only example of a crouched burial. Most of the bodies were placed in the burial pits with their heads towards the southeast, while in four cases (nos. 12. 40, 61a.b) an opposite orientation was chosen and in two cases (nos. 11, 59) the heads lay to the east. The anthropological composition of the group of individuals buried in the Lyalovo cemetery resembles a normal palaeo-population of hunter-gatherers: seven individuals were sub-adults, most of whom had died as infants; among the remaining individuals, six 


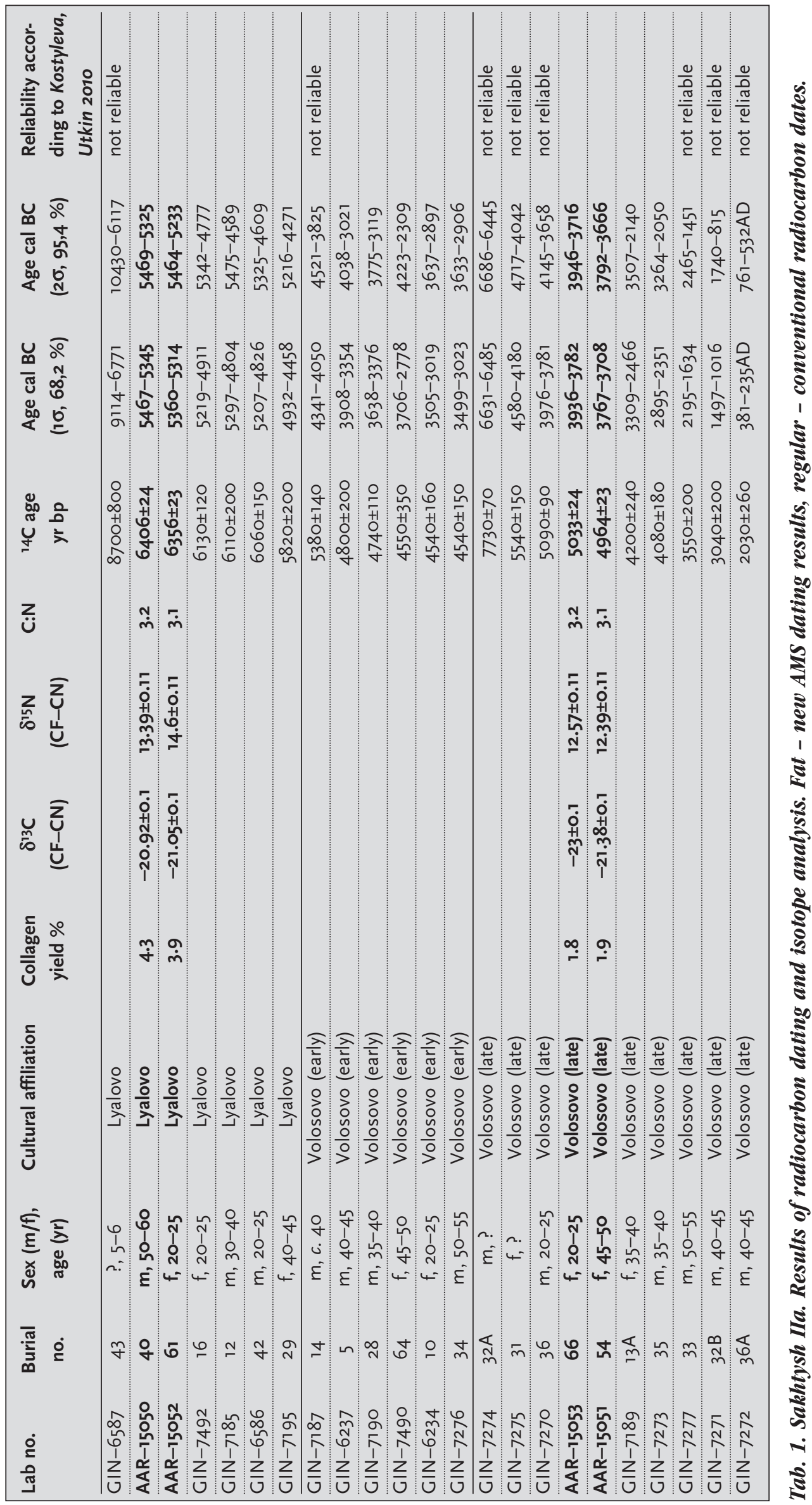


were identified as women and three as men (one adult: sex unknown) (Kostyleva, Utkin 2010.40).

The fills of the burial pits contained various finds, such as animal bones, stone artefacts, tooth pendants of elk and bear, and sherds of Upper Volga and early Lyalovo ceramics; later phases of the Lyalovo culture were not represented (Kostyleva, Utkin 2010.37). Traces of red ochre were documented in four graves (nos. 29, 43, 59, 61); grave goods were present in only four burials (Kostyleva, Utkin 2010. 39). The most extensive set of artefacts (two bone daggers, a harpoon and an animal tooth pendant) had been given to the 20- to 25-year-old woman in grave no. 22. One of the daggers bears a human face carved with a few well-placed incisions at the handle end (Fig. 5). In grave no. 40, the burial of a 50 to 60 year old man, a pointed tool made from an elk metatarsal was found close to the left shoulder (Fig. 6). The young woman in grave 61 was equipped with three bone artefacts, among them a pointed bone and a knife (Fig. 7). A small embryo-shaped clay figurine came to light under the chest of the 35 to 45 year old woman in grave no. 65 (Fig. 12.1). Similar clay images are widely known in the northeastern European forest zone from Finland to the Eastern Baltic and Northern Russia, where they are associated with Middle Neolithic Comb Ceramic complexes. In the area of the Pit-Comb Ceramic groups further south which include the Lyalovo culture, they are less common (Kashina 2004; Nunez 1986). The limited set of grave goods encompassing merely bone tools and animal tooth ornaments and the large portion of burials with no artefacts observed at Sakhtysh IIa are in accordance with the burial customs documented at the few other known early Lyalovo cemeteries Sakhtysh II, Yazykovo 1 and Lovcy (Kostyleva, Utkin 2010.39; 2012.233-234).

Four conventional radiocarbon dates on human bone determined at the radiocarbon laboratory of the Geological Institute of the Russian Academy of Sciences in Moscow range between $c .5500$ and 4500 calBC (Tab. 1; Fig. 13) and are in general agreement with the proposed early Lyalovo context (Engovatova 1998; Zaretskaya, Kostyleva 2010). A further conventional radiocarbon date from this complex (GIN6587) would appear several millennia too old and must be regarded as unreliable due to its large standard deviation ( \pm 800$)$ (Kostyleva, Utkin 2010.41).

\section{The Volosovo cemetery}

The 57 burials of the Late Neolithic/Early Metal Age phase are distinguished from the earlier burials by

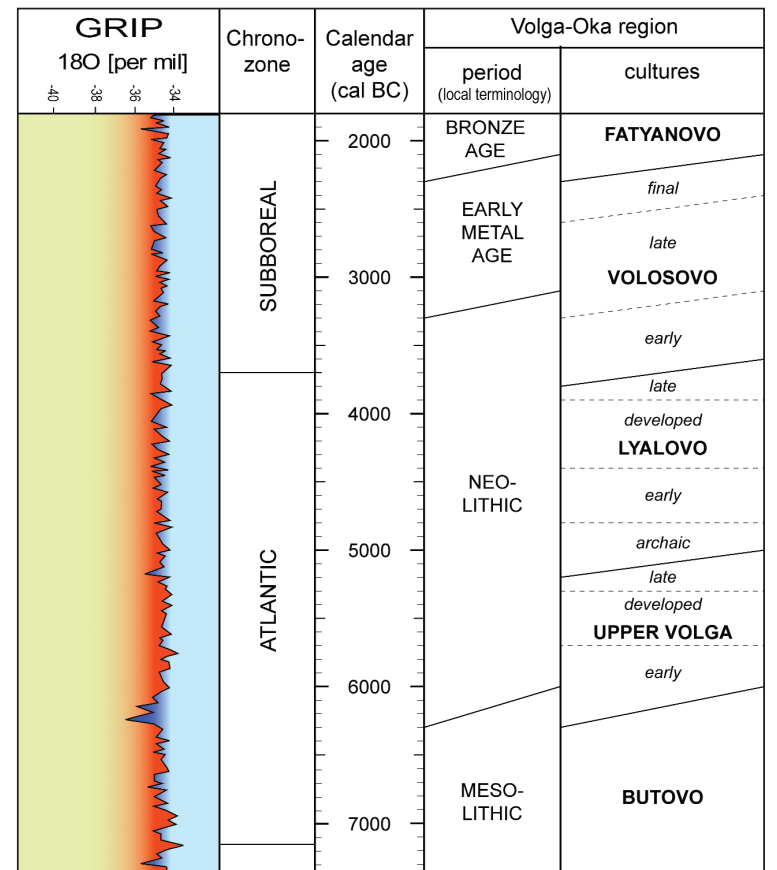

Fig. 3. Chronology of prehistoric cultural groups in the Volga-Oka region, Central Russia, and climatic development according to Greenland ice core data (GRIP project, Johnsen et al. 1992; 1997) showing the 6.2ka event.

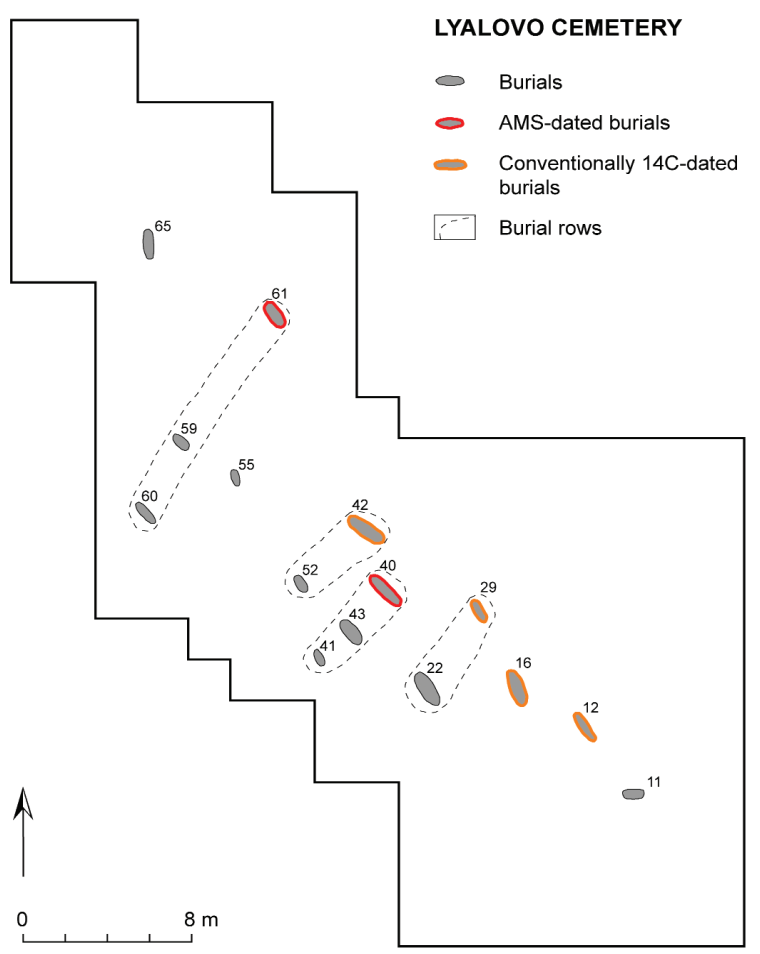

Fig. 4. Sakhtysh IIa. Middle Neolithic cemetery of the Lyalovo culture (modified after Kostyleva, Utkin 2010.Fig. 36).

their higher stratigraphic position and by a different spatial arrangement (Fig. 8). Associated with this phase were two ritual hoards and a structure inter- 
preted as a 'sanctuary' (Kostyleva, Utkin 2010.49-50). This consisted of a pentagonal construction with a large pit inside which a unique life-size human mask made of elk antler was discovered (Fig. 12.3).

The burials were found at a maximum depth of $0.53 \mathrm{~m}$ below the modern surface within the Volosovo cultural layer (Kostyleva, Utkin 2010.41). No traces of burial pits were detectable, and the preservation conditions of the skeletal remains are generally poorer. Only about twenty skeletons were preserved more or less completely, while eight interments had been entirely destroyed. Dislocated human bone fragments and typical Volosovo amber ornaments found in the cultural layer indicate an even higher number of destroyed graves (Kostyleva, Utkin 2010.42). The Volosovo burials were positioned perpendicular to the course of the River

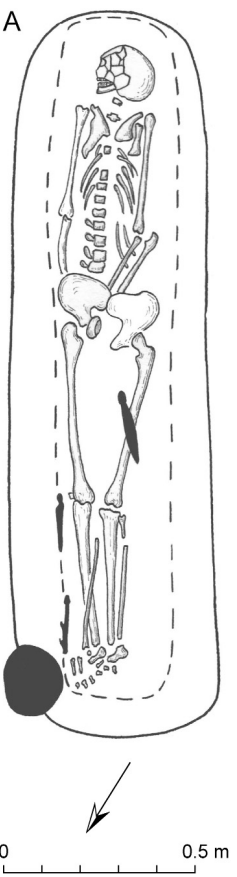

B

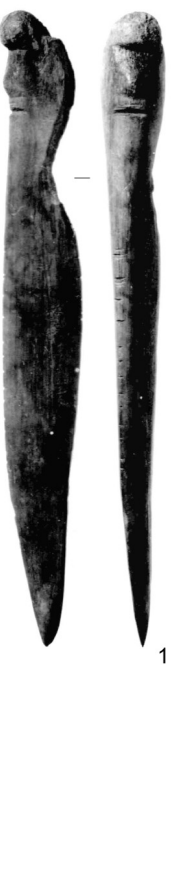

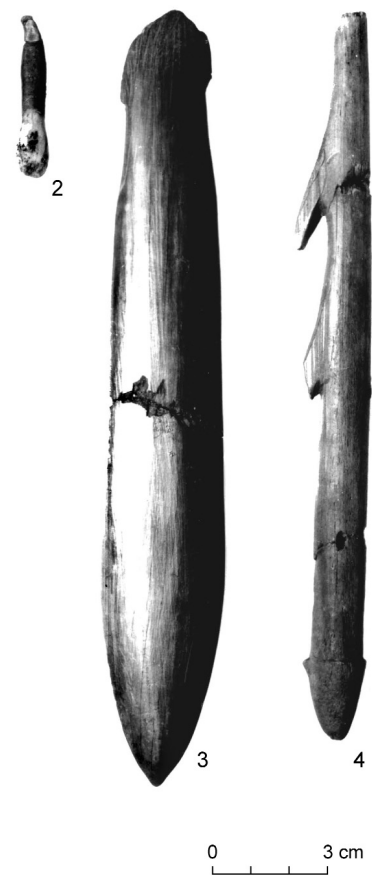

Fig. 5. Sakhtysh IIa. Burial no. 22. A - plan of burial; B - grave goods (1, 3, 4 - bone; 2 - animal tooth) (after Kostyleva, Utkin 2010.Fig. 39. 1-4).
Koika (see Fig. 8) and formed rows of varying length, mostly orientated NW-SE (Kostyleva, Utkin 2010. 40). Four of the graves (nos. 8, 44, 49, 54) do not seem to be connected to any of the rows. From the spatial and stratigraphic position of the graves and the adornment with grave goods, a subdivision into two phases has been suggested for the Volosovo cemetery: among the early graves are rows A, $\mathrm{B}$, and E ( 0.25 to $0.5 \mathrm{~m}$ below modern ground surface) while rows B, $\Gamma, \triangle$ and $Ж$ are associated with a younger sub-phase ( 0.15 to $0.25 \mathrm{~m}$ below modern ground surface) (Kostyleva, Utkin 2010.46).

The graves contained single burials, the only possible exception being grave no. 50, where some infant bones were found together with the skeletal remains of an adult woman (Kostyleva, Utkin 2010. 42). All of the 51 deceased whose position in the grave could be determined had been buried in an extended supine position, 49 of them with the head to the SW towards the river (no. 47: head to NW; no. 49: head to the N). The results of the anthropological study suggest that here, too, a normal population was buried with the ratio between adult males and females more or less balanced ( 26 men, 23 women) (Kostyleva, Utkin 2010.51-53, Tab. 5). Children are represented by only five individuals (one infant). However, this low number might be due to the less favorable preservation conditions compared to the Lyalovo burials.
In the Volosovo graves, no evidence of the use of ochre in the burial rites was found (Kostyleva, $U t$ kin 2010.42). In 36 graves, pendants and buttons made of amber, stone, bone and animal teeth were found and, according to their position in association with the skeletal remains, it is likely that most of these ornaments had been attached to the clothing. Almost $90 \%$ of the 367 amber artefacts stem from two graves, among them grave no. 15, where the original arrangement of the buttons on the clothing of a 20- to 25-year-old man was still preserved (Fig. 9). Such extensive adornment with amber ornaments has been identified as a characteristic trait of the early phase of Volosovo burial rites (Kostyleva, Utkin 2010.256). For the second phase, a simpler adornment with just a few tooth and stone pendants seems to be typical (Kostyleva, Utkin 2010.256) (Figs. 10, 11). In several graves, animal remains such as bear fangs, beaver jaws and elk antler were present close to the human bones. An anthropomorphic bone pendant was discovered in the burial of a 40to 45-year-old woman (grave no. 58) (Fig. 12.2).

To determine the absolute chronology of the Volosovo cemetery, a series of 32 samples of human bone from 29 graves were analysed by conventional radiocarbon dating at the Russian Academy of Sciences (Tab. 1). Fifteen of the samples did not provide sufficient collagen, and seven dates gave results that are not in accordance with the established chronolo- 


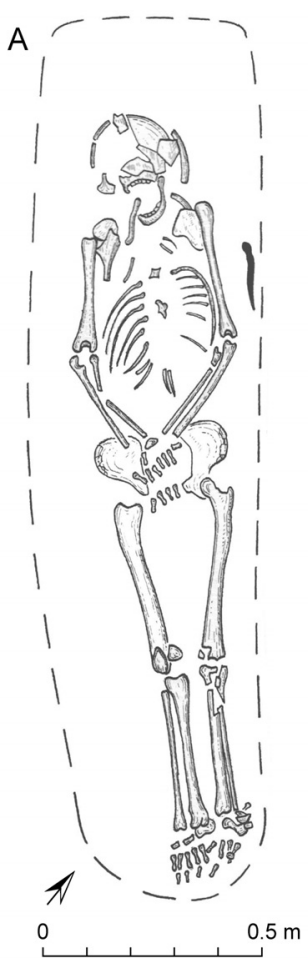

B

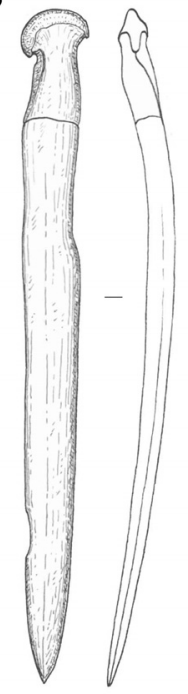

0

$3 \mathrm{~cm}$

Fig. 6. Sakhtysh IIa. Burial no. 40. A - plan of burial; B - bone tool (after Kostyleva, Utkin 2010. Fig. 41.1-2).

gical framework of the Volosovo culture and/or the stratigraphic situation at the site (Fig. 13)1. Only five dates for the early phase ( $4^{\text {th }}$ millennium calBC) and two for the later phase (c. 3500-2500 calBC) have been regarded as reliable by the excavators (Kostyleva, Utkin 2010.48) (Fig. 13).
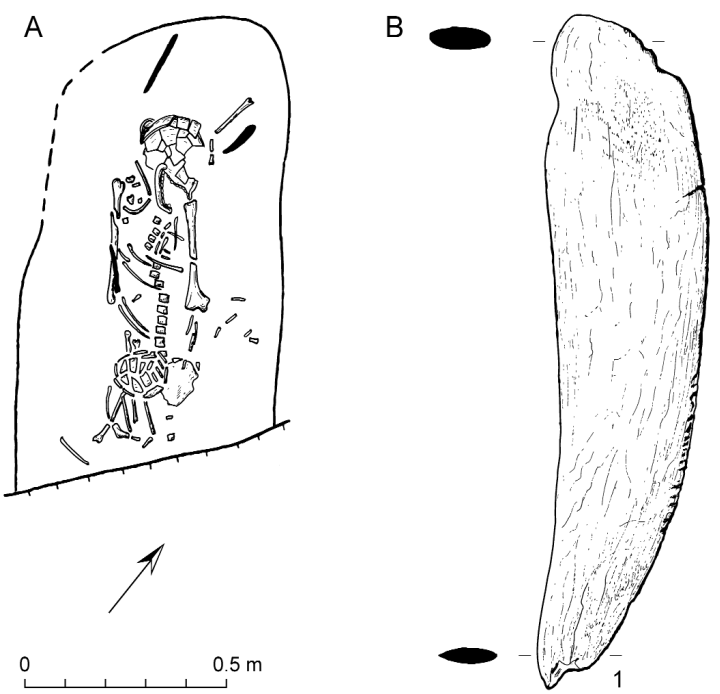

AMS dating and isotopic analyses of human remains from Sakhtysh IIa

\section{Methods}

The archaeometric analyses conducted on Sakhtysh IIa human bone samples encompassed AMS radiocarbon dating and the determination of stable carbon and nitrogen isotope ratios.

Measurements of carbon and nitrogen isotope ratios in bone collagen are among the most important methods in archaeological research for acquiring information on dietary components in the subsistence of individuals and investigating more general questions concerning variations in diet between groups, temporal developments such as the introduction of new food stuffs, breastfeeding patterns etc. (Eriksson 2006.184; Fischer et al. 2007). Body tissue is synthesised out of dietary components, and the isotopic composition of collagen from compact bones of adult humans reflects the average diet over approximately two decades prior to death (Olsen, Heinemeier $2007.340)$. The carbon isotope ratio $\left(\delta^{13} \mathrm{C}\right)$ yields information on the proportion of marine (higher values) versus terrestrial food components (more negative values), while a differentiation between terrestrial and freshwater components can be more problematic due to overlapping ranges (see Figs. 14$17)$. The nitrogen isotope ratio $(\delta 15 \mathrm{~N})$ reflects the trophic level of the consumer, which increases by $c$. $3.5 \%$ in each step up the food chain. Thus, carnivores have higher $\delta 15 \mathrm{~N}$ values than herbivores from the same ecological system. Marine and freshwater diets generally result in higher $\delta^{15} \mathrm{~N}$ values than diets based on terrestrial food, because aquatic food webs are longer than terrestrial ones (Eriksson 2006.185, Fig 1; Olsen, Heinemeier 2007.340). A slight increase in the $\delta 13 \mathrm{C}$ of $c .1 \%$ can also be observed with each trophic level shift (Olsen, Heinemeier 2007.340).

An important method for more precisely reconstructing the composition of the diet of prehistoric people in a certain region from their stable carbon and nitrogen isotopic ratios is the comparison with local faunal isotopic data derived preferably from

Fig. 7. Sakhtysh IIa. Burial no. 61. A - plan of burial; B - grave goods (bone) (after Kostyleva, Utkin 2010.Fig. 43.2-3, 5).

1 For example, the dates for the overlapping graves $32 \mathrm{~A}$ and $\mathrm{b}$ resulted in a 'Mesolithic age' for the upper and a 'Late Bronze Age' date for the lower skeleton (Kostyleva, Utkin 2010.47; see Tab. 1). 


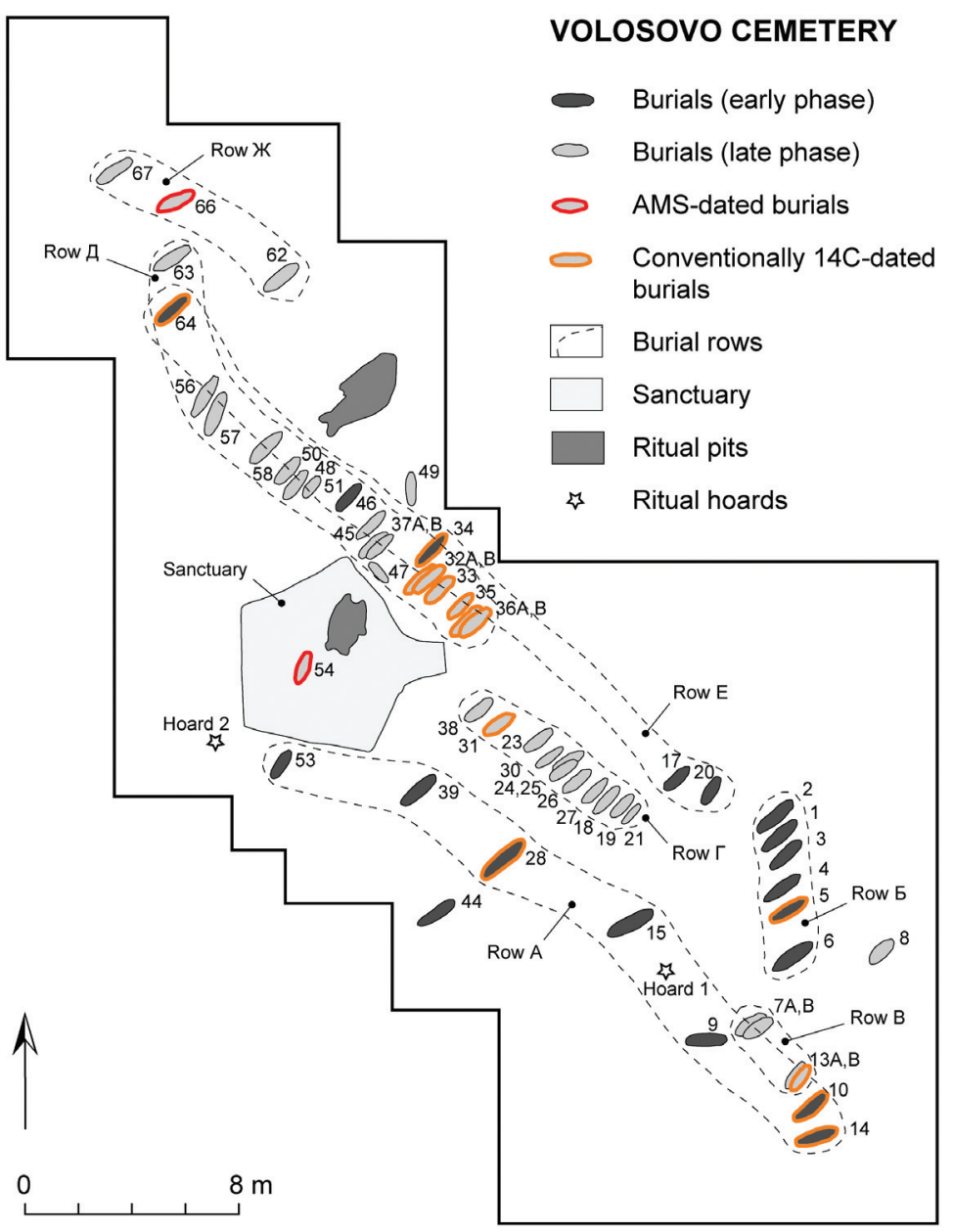

Fig. 8. Sakhtysh IIa. Late Neolithic/Early Metal Age cemetery of the Volosovo culture (modified after Kostyleva, Utkin 2010.Fig. 44).

the age of the carbonate in the water, freshwater reservoir ages can vary considerably with time and geographical location (Fischer et al. 2007; Olsen et al. 2010). Organisms such as molluscs and fish are affected by the reservoir age of their aquatic habitat, and humans, whose diet includes organisms from the aquatic food web, will also show varying reservoir ages, depending on the portion the aquatic food makes up in their entire nutrition.

For the detection of the presence and also the absolute value of a possible reservoir age in human bones from graves, a good method is to compare radiocarbon dates of human remains and remains of terrestrial animals from the same burials (i.e., grave goods made of bone). Due to their land-based diet, terrestrial animals such as red deer and aurochs have most probably not been influenced by aquatic reservoir

the same chronological context (Eriksson 2006.185; Olsen et al. 2010). Such data provide the isotopic ranges of various food stuffs people could have consumed and show the ranges in which human consumers would have to be expected one level up in the food chain.

Due to this information on dietary components, the stable isotope ratios can help to address the problem of whether the radiocarbon ages of the sampled individuals have been affected by a reservoir effect. Both the marine and the freshwater reservoir effects are caused by the fact that aquatic organisms are depleted in ${ }^{14} \mathrm{C}$ relative to the atmosphere, which leads to unduly old radiocarbon ages compared to contemporaneous terrestrial creatures (Olsen, Heinemeier 2007.340). The freshwater reservoir age, which is of interest in the inland context of the Sakhtysh IIa samples, is the result of dissolved $\mathrm{CaCO}_{3}$ from fossil carbonate deposits. Depending on the amount and effects and can therefore serve as proxies for determining the true date of the graves and the humans buried in them (see e.g., Olsen, Heinemeier 2007. 345; Olsen et al. 2010).

AMS dating and isotopic analyses of the Sakhtysh IIa samples were carried out at the AMS ${ }^{14} \mathrm{C}$ Dating Centre at the University of Århus. 2 The $\delta^{13} \mathrm{C}$ and $\delta^{15} \mathrm{~N}$ isotopic values of the samples were measured by high-precision stable isotope mass spectrometry.

\section{Results}

Samples of human remains from two graves of the Lyalovo cemetery (graves 40 and 61) and from two graves supposedly associated with the younger phase of the Volosovo cemetery (graves 54 and 66) were analysed (Tab. 1, Fig. 13). All four samples provided sufficient collagen after ultra-filtration, with the Lyalovo samples being in better condition (3.9-4.3\%; Volosovo samples: 1.8-1.9\%).

2 Collagen was extracted from the bone matter following the protocol of DeNiro and Epstein (DeNiro, Epstein 1981; Jørkov et al. 2007). The collagen was then checked according to the guidelines by DeNiro and van Klinken (DeNiro 1985; van Klinken 1999). The results of the AMS measurement are reported in accordance with international convention (Stuiver, Polach 1977; Reimer et al. 2009) as conventional radiocarbon years bp (before present $=1950$ ). The dates have been corrected for the natural isotopic fractionation by normalizing the result to the standard $\delta 13 \mathrm{C}$ value of wood $(-25 \%)$ (Andersen et al. 1989). 
The stable carbon and nitrogen isotope values represent the first such information for the Sakhtysh complex and, indeed, Stone Age burial sites of northwestern Russia in general. All four samples show comparatively negative ${ }^{13} \mathrm{C}$ values between -20 and $-23 \%$; their $\delta 15 \mathrm{~N}$ values are rather high, ranging from 12.4 to $14.6 \%$ o (Tab. 1). These values indicate an aquatic component in the diet, and on this background we might expect possible reservoir effects in the dating results. Irrespective of this potential problem, the AMS radiocarbon dates confirm the presence of two phases at the burial site. The dates from the Lyalovo graves 40 and 61 fall into a narrow range of 5469-5233 calBC (95.4\% probability), with an overlap from 5464-5325 calBC, while the dates from the Volosovo graves 54 and 66 are approx. 1500 years younger, covering a range of 3946-3666 calBC (95.4\% probability) overlapping from $3792-3716$ calBC.

\section{Discussion}

Stable carbon and nitrogen isotope ratios: $\mathrm{hu}$ man diet and the freshwater reservoir effect Because isotopic data for the background fauna and the humans of the Upper Volga region are not yet available, it is necessary to use information from the neighboring territories. On the basis of data from the Baltic and Northern Europe, $\delta 15 \mathrm{~N}$ values of $\geq$ $11 \%$ in human bone show an increasing portion of aquatic food in the diet. In combination with $\delta 13 \mathrm{C}$ values of $\leq-22 \%$, they can be related to freshwater organism-dominated diet, while values from $c,-17$ to $-12 \%$ indicate the increasing consumption of marine food (Fischer et al. 2007).

The isotopic signatures of the four Sakhtysh samples with their ${ }^{13} \mathrm{C}$ values between -20.9 and $-23.0 \%$, and $\delta 15 \mathrm{~N}$ values from 12.4 to $14.6 \%$, strongly indicate a considerable intake of freshwater-derived food by these individuals. No great differences in the stable carbon and nitrogen isotope ratios can be observed between the Lyalovo and the Volosovo samples. Only when a larger set of data is available can it be decided whether the slightly lower $\delta^{13} \mathrm{C}$ values of the two Volosovo samples have a more systematic significance.

Data published recently for the burial sites at Minino I and II provide an excellent opportunity to test this interpretation (Fig. 1). The sites yielded 39 graves from the Mesolithic and Neolithic period, and 22 faunal bones and 35 humans were analysed for carbon and nitrogen stable isotopes (Wood et al.
2013). The isotopes for herbivores are in the expected range, with a $\delta^{15} \mathrm{~N}$ of $c .2$ to $6 \%$, while samples of pike and waterfowl show $\delta^{15} \mathrm{~N}$ of $c .9 .0 \%$. Because the values for the human bone collagen are enriched in $\delta^{15} \mathrm{~N}$ by $c .4 .2 \%$ above the fish and waterfowl (11.7 to $16.2 \%$ ), there is no doubt that herbivores were of little relevance, and aquatic resources played a very important role in the human diet at Minino (Wood et al. 2013.169). The data from Minino correspond very well with the values obtained on the Sakhtych burials (Figs. 14-15) and strongly support the interpretation of the Sakhtych values to be caused by the high proportion of fresh water fish or aquatic food consumption.

If we view the isotopic values from the four Sakhtysh IIa burials against the background of the data from the famous prehistoric cemetery of Zvejnieki in Latvia (Eriksson 2006) (Fig. 16), we see that their high nitrogen ratio strongly argues for a substantial freshwater component in the diet combined with some terrestrial protein intake. The humans show nitrogen isotopic values similar to the otter, with its diet dominated by freshwater fish, while the values for brown bear, a typical omnivore, are located much lower in the terrestrial range. The Sakhtysh humans can also be well compared to the Zvejnieki human remains (Fig. 17). With one exception indicating a substantial marine input in the diet, all other human samples from Zvejnieki are in the region of terrestrial and freshwater food consumers. An interesting chronological trend can be noted that involves a shift from a more freshwater-species orientated diet in the Mesolithic towards a higher input of terrestrial animal and plant food in the Late Neolithic and Bronze Age (Eriksson 2006.193-196). The Sakhtysh IIa samples, with their high nitrogen isotope values, are in accordance with the first dietary type, and there is no doubt that they had a Mesolithic way of life as hunter-fisher-gatherers.

An analogous picture evolves when the Sakhtysh IIa isotopic data is compared to evidence from Central and Northern Europe. In Figure 18, the Russian samples are plotted against isotopic data from Denmark. Here, the Sakhtysh values are even more clearly located in the area where humans with a diet based on freshwater protein would be expected. The Sakhtysh samples fall into almost exactly the same range as the human samples from the Ostorf cemetery in northern Germany, a burial community of fishers and hunters thriving in the late $4^{\text {th }}$ millennium calBC in a Neolithic farming environment (Lübke et al. 2007; Olsen et al. 2010) (Fig. 19). For the Ostorf hu- 


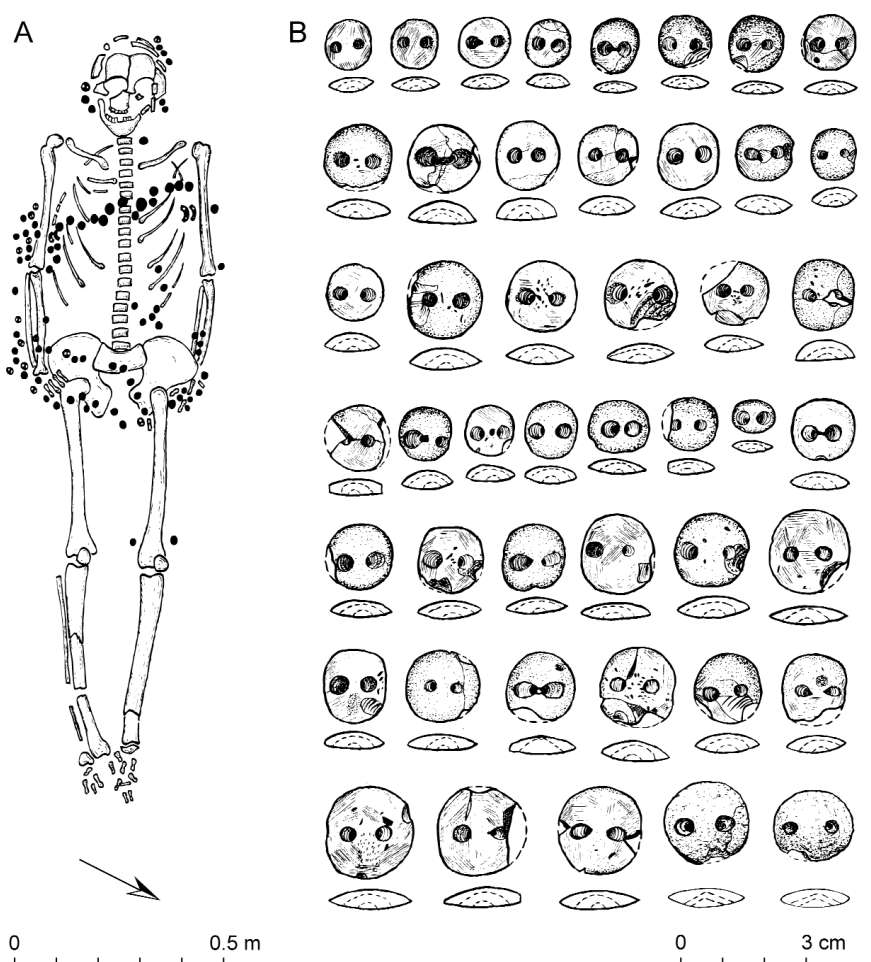

Fig. 9. Sakhtysh IIa. Burial no. 15. A - plan of burial; B grave goods (amber) (after Kostyleva, Utkin 2010.Fig. 53). dates received for the human bone samples are probably too old due to a freshwater reservoir effect.

\section{The dating of the Sakhtysh IIa burials}

Compared to the set of existing conventional radiocarbon dates, the four new AMS dates are outstanding by their high precision with standard deviations of no more than $\pm 24 \mathrm{ra}$ diocarbon years (Tab. 1, Fig. 13). In the $95.4 \%$ probability range, the calibrated AMS dates thus cover just over two centuries, compared to more than a millennium for many of the conventional dates. Also, the reliability of the AMS dates appears to be altogether higher, as both dates in each culturally determined pair (Lyalovo and Volosovo, respectively) lie close together, and outliers, as can be seen among the conventional dates (Fig. 13: greyshaded dates) are not present. A third observation concerns the absolute dates of the new samples: for both the Lyalovo and the Volosovo groups, they are somewhat older than the respective ranges of those dates which were regarded as reliable by Kostylemans, reservoir ages of up to $c$. 700 years have been detected, which are thought to be the result of a freshwater reservoir effect (Olsen, Heinemeier 2007. 345-347). In contrast, human bone data from megalithic tombs and Late Neolithic and Early Bronze Age burials from the same region show substantially lower nitrogen isotope ratios indicating a shift in the diet towards the terrestrial plants and animals typical of farming communities.

In summary, we can conclude on the basis of data from other sites of the European forest zone that the stable carbon and nitrogen isotope signals measured in the Sakhtysh IIa human samples are in accordance with a diet largely based on freshwater food while terrestrial food played a less prominent role in the subsistence. This means that the AMS radiocarbon

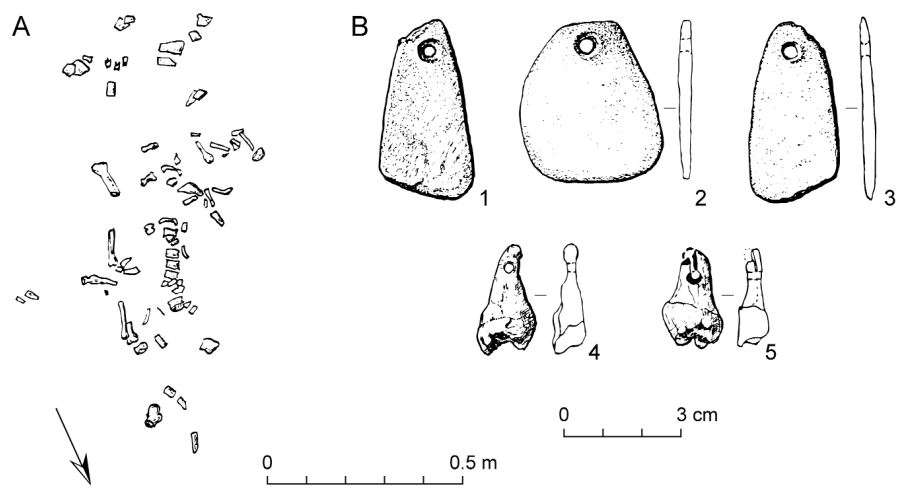

va and Utkin (2010) (Fig. 13: black-shaded dates). For the Lyalovo burials, the age offset from the nextyounger conventional dates encompasses more than 200 radiocarbon years (although due to the large standard deviation of the conventional dates, the calibrated ranges do overlap), and for the Volosovo samples supposedly belonging to the younger phase, even the four 'reliable' conventional dates of the early Volosovo phase are all more than 150 radiocarbon years younger than the new dates.

These slightly older - compared to the existing dates - absolute ages of the AMS dates might be due to improved methods of bone sample preparation, which have significantly advanced in recent years: contaminations caused $e . g$. by intrusive younger carbon can now be removed more effectively (e.g., Jacobi et al. 2009). Reservoir effects, on the other hand, should not be responsible for this particular age offset, as it can be presumed that the conventional dates on human remains of the respective phases would have reservoir ages more or less similar to the new samples, because it is likely that the diet

Fig. 10. Sakhtysh IIa. Burial no. 54. A plan of burial; $B$ - grave goods (1-3 stone; 4, 5 - animal tooth) (after Kostyleva, Utkin 2010. Fig. 62. 4-9). 


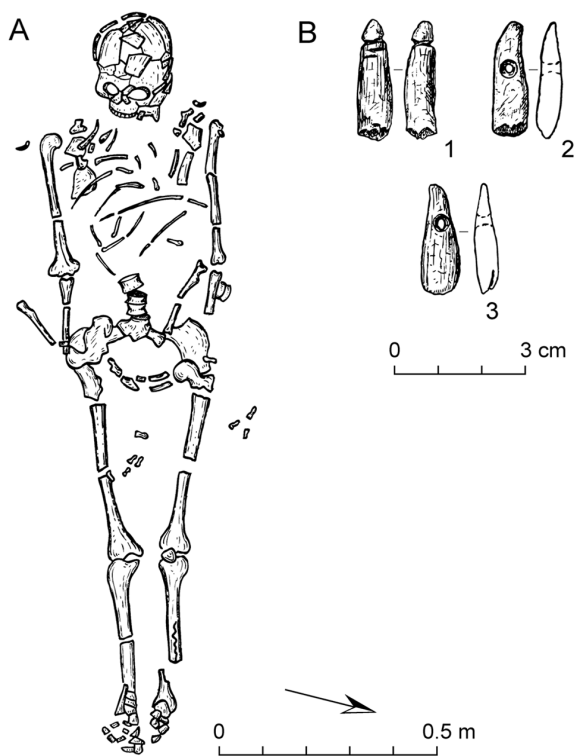

Fig. 11. Sakhtysh IIa. Burial no. 66. A - plan of burial; B - grave goods (animal tooth) (after Kostyleva, Utkin 2010.Fig. 64.4-7).

within each funerary community did not differ very much.

That significant reservoir ages can be expected in the radiocarbon dates of human individuals from this period is also suggested by results from the Stone Age cemetery of Minino at Lake Kubeno approx. $300 \mathrm{~km}$ north of Sakhtysh. At this site, paired samples of human remains and animal bone grave goods have been radiocarbon dated from Neolithic graves (Kostyleva, Utkin 2012.238). In most cases the human bone yielded much earlier results than the bones of herbivores and the age offset varies between $c$. 350 and 650 years (Wood et al. 2013) with an average of $c$. 490 years. The animal bone samples suggest a dating of the graves to the turn of the $6^{\text {th }}$ to the $5^{\text {th }}$ millennium calBC. 3 The substantial reservoir effects are comparable to those observed in the hunter-fisher population at Ostorf, northern Germany, which has been described above. Unfortunately, it is not yet possible to see a correlation between the isotope values and the age offset. In Minino the reservoir age seems to be similar in cases where the carbon and nitrogen stable isotope values are rather different (Wood et al. 2013; Olsen et al. 2010).

\section{Lyalovo graves}

If we assume that the new AMS dates are the more reliable results, then burials no. 40 and 61 of the Lya- lovo phase are now dated to the third quarter of the $6^{\text {th }}$ millennium calBC. According to the established chronological framework, based on radiocarbon dates from various contexts and materials, the Lyalovo culture is subdivided into the four phases (archaic, early, developed, late), the first two of them being relevant for the discussion of the early Lyalovo graves of Sakhtysh IIa (Zaretskaya, Kostyleva 2010). In this scheme, the archaic phase is assigned to a time frame of 6200-5900 bp (c. 5220-4730 calBC) and the early phase to the period of 5900 5600 bp (c. 4790-4370 calBC). Of the five dates older than $6000 \mathrm{bp}$, however, three stem from Sakhtysh IIa burials. Dates of terrestrial samples securely associated with archaic Lyalovo cultural layers start at $6100 \mathrm{bp}$ (c. 5030 calBC) (Zaretskaya, Kostyleva 2010.Tab. 1).

Therefore, the two new AMS dates for the burials of the early part of Lyalovo culture from Sakhtysh IIa appear 200 to 400 years too old compared to the onset of the Lyalovo culture, and three of the four conventional dates of the graves cover the very beginning of its archaic phase. The most likely explanation for these very or too early ages within the chronological framework is a freshwater reservoir effect
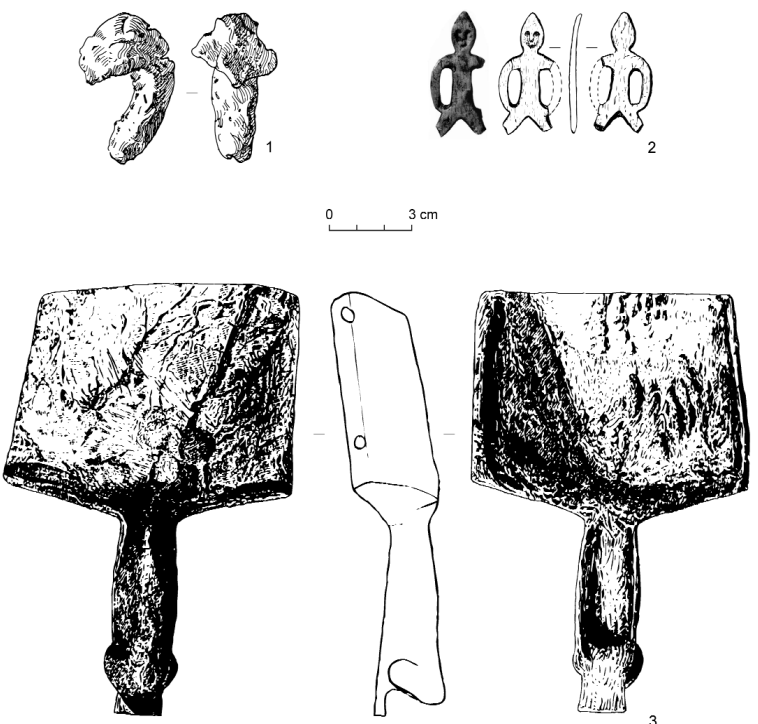

Fig. 12. Sakhtysh IIa. Anthropomorphic images. 1 Embryo-shaped clay figurine from Lyalovo burial no. 65; 2 - anthropomorphic bone pendant from Volosovo burial no. 58; 3 - elk antler mask with life-size human facial features from Volosovo sanctuary (after Kostyleva, Utkin 2010.1, Fig. 43.4, 2, Fig. 63.3; 3, Fig. 69).

3 In grave no. 4, the results were $6590 \pm 50 \mathrm{bp}$ (AAR-5789; 5618-5479 calBC at 95.4\% probability) for the human and $6165 \pm 45 \mathrm{bp}$ (AAR-5788; 5286-4988 calBC at 95.4\% probability) for the animal sample; in grave no. 14 the human bone gave an age of $6680 \pm 50$ (AAR-5787; 5706-5511 calBC at 95.4\% probability) and the animal bone an age of $6140 \pm 50 \mathrm{bp}$ (AAR-5790; 5217-4947 calBC at $95.4 \%$ probability). 
(see above). As the archaeological situation at Sakhtysh IIa does not suggest a particularly early chronological position of the graves within the early part of the Lyalovo culture - the burial pits were cut from the Lyalovo cultural layer which had already had some time to accumulate - rather substantial reservoir offsets of 500 years seem possible. To reliably identify and quantify the reservoir ages of the human remains, paired dates of human bone and terrestrial animal bone from the same burials are necessary.

\section{Volosovo graves}

The absolute chronology of a three-phase model for burial customs in the Late Neolithic/Early Metal Age Volosovo culture is based almost exclusively on conventional radiocarbon dates from Sakhtysh IIa (Kostyleva, Utkin 2008a.233) (Tab. 1, Fig. 13). The earliest group is supposed to range from 47504500 BP (c. 3630-3100 calBC), the second group dates between 4250-4000 BP (c. 2900-2480 calBC), and the youngest group, which is not represented at Sakhtysh IIa, is thought to have existed between 4000-3750 BP (c. 2570-2140 calBC). However, due to sometimes problematic conventional dates of the Sakhtysh IIa burials (Fig. 13), this chronological framework cannot be regarded as entirely reliable.

On archaeological grounds, the two AMS-dated graves, No. 54 and 66, have been assigned to the second phase of the Volosovo culture cemetery. The dates, however, fall into the first half of the $4^{\text {th }}$ millennium calBC and are somewhat older than the conventional dates of the early Volosovo phase at Sakhtysh IIa; the divergence from the two accepted conventional dates of the younger phase accounts to $c$. 7501000 radiocarbon years. Therefore, the AMS dates either put a question mark on the association of the AMS-dated graves with the younger phase, or they even challenge the subdivision of the Volosovo graves at Sakhtysh IIa into two chronological phases. At the same time, freshwater reservoir effects of ap- prox. 500 years have to be expected for the radiocarbon dates of the Volosovo human remains, as the stable isotopes of the two analysed samples indicate a high freshwater-derived protein component in the diet equal to that of the Lyalovo samples.

In conclusion, the archaeometric analyses of four human bone samples from Sakhtysh IIa have yielded new information both on the chronology of the cemetery and on the diet and economy of the buried population. The presence of two distinct chronological phases (Lyalovo and Volosovo) was able to be confirmed, while the details of sub-division of the Volosovo phase into two sub-phases are now put into question, and only the early sub-phase has been confirmed by the AMS dates. Analysis of the stable carbon and nitrogen isotope ratios in the samples suggests a high freshwater protein component in the diet both of the Lyalovo and Volosovo individuals. Together with the observation that the radiocarbon 
dates of the Sakhtysh graves appear altogether too old compared to the established chronological frameworks, these findings suggest considerable reservoir ages of about 500 years in the dating results of the human samples due to freshwater reservoir effects.

The important role that freshwater resources played in the life and subsistence of the Stone and Early Metal Age population of the Upper Volga region is confirmed by a range of archaeological findings and other indicators. In the Mesolithic Butovo and the Early Neolithic Upper Volga cultures, the importance of fishing in the economy is attested to by the choice of settlement places on the banks of lakes and rivers and also by archaeological and faunal materials (Krainov 1996.171; Zhilin 2006). The sites of the Lyalovo culture of the Middle and Late Neolithic yielded numerous remains of fishing gear and constructions, as well as large quantities of fish bones and scales, and it is presumed that fishing had become the most important subsistence strategy for providing daily nutrition (Gurina, Krainov 1996.180). For the Volosovo culture, even ceramic technology shows the prominent position of aquatic resources in everyday life: molluscs and fishbones but also feathers of aquatic birds, were frequently used as tempering material (Petrova 2008).

\section{Future perspectives}

First results on human bone from the Sakhtysh IIa cemetery illustrate the important role of modern archaeometric methods for the study of Stone Age burial sites and the lifestyle in the Eastern European forest zone.

The new dating and isotopic results show clearly that radiocarbon dates derived from Stone and Early Me- tal Age human remains from this region must be interpreted with caution because of reservoir ages and should by no means be regarded as true ages on which a reliable absolute chronology can be built. A central future task will therefore be the production of paired dates on human remains and terrestrial animal bone from closed grave contexts in order to more precisely judge the presence and also the degree of possible reservoir ages in the radiocarbon dates.

The determination of stable carbon and nitrogen isotopes in further archaeological samples will shed light on developments in the diet of individuals and groups over the course of time, and on the basis of this information, continuities and changes in subsistence strategy and economy can be traced. The chronological range should be extended to younger periods (Bronze Age, Iron Age) to identify fundamental innovations such as the transition to agriculture and animal husbandry. Of crucial importance will be the determination of isotope ratios in local animal and plant species from various habitats in order to build up a better reference data base to interpret the respective isotope values in humans.

The authors would like to thank the German Science Foundation for supporting this study (DFG grant no. HA 2961/2-1, TE 259/5-1). Many thanks are due to Prof. Mihael Budja (Ljubljana) for his invitation to present our results at the 19th Neolithic Seminar at the University of Ljubljana and the much-valued possibility of publishing this study in the Documenta Praehistorica. 


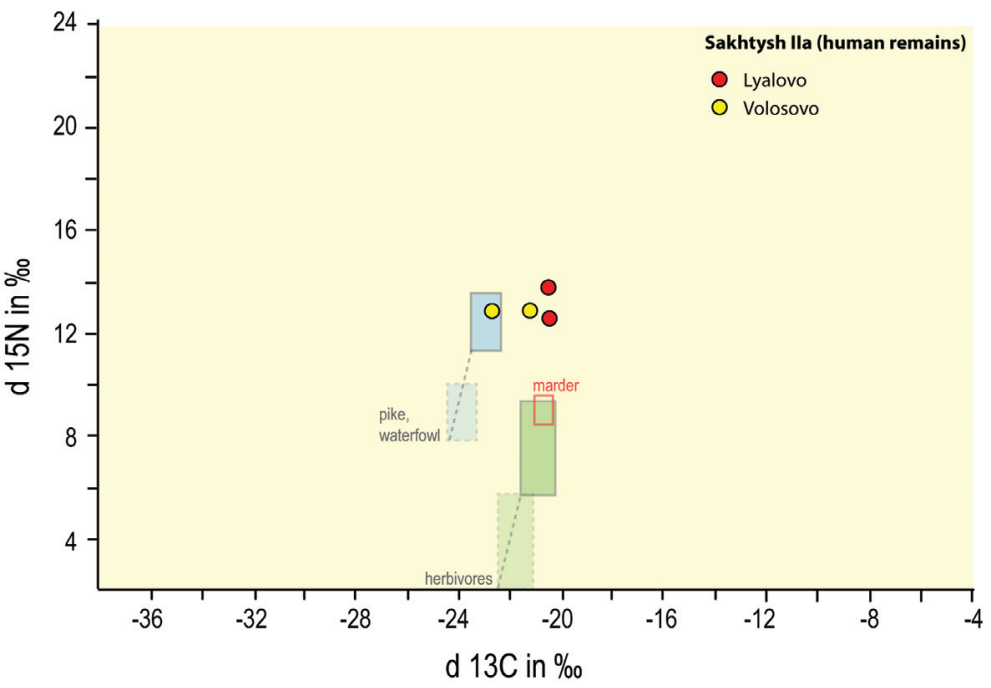

Fig. 14. Carbon and nitrogen isotope values of the Sakhtysh IIa humans against the background of isotope ranges of animals from the mixed cultural layer at Minino, north-west Russia (light-shaded boxes) depicted together with the ranges of their consumers (dark-shaded boxes) after a standard trophic level shift of 1\%o for $813 \mathrm{C}$ and $3.5 \%$ for $815 \mathrm{~N}$. Isotope range of marten is depicted separately (red frame) (Minino isotope ranges: after Wood et al. 2013).
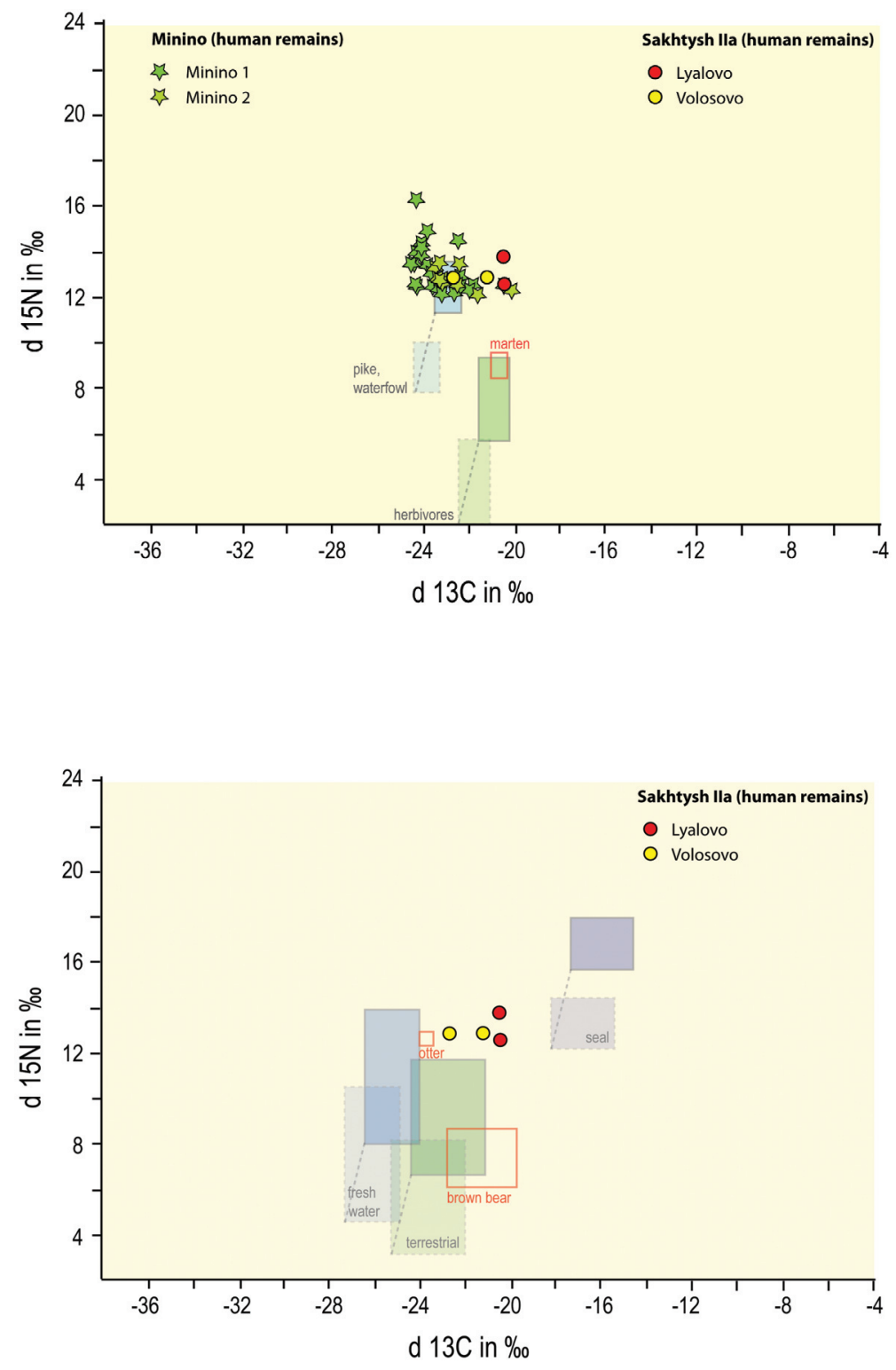

Fig. 15. Carbon and nitrogen isotope values of the Sakhtysh II humans and humans from Minino 1 and 2 , against the background of isotope ranges of animals from the mixed cultural layer at Minino, north-west Russia (light-shaded boxes) depicted together with the ranges of their consumers (dark-shaded boxes) after a standard trophic level shift of $1 \%$ for ${ }^{13} \mathrm{C}$ and $3.5 \%$ for $\delta^{15} \mathrm{~N}$. Isotope range of marten is depicted separately (red frame) (Minino isotope ranges: after Wood et al. 2013).

Fig. 16. Carbon and nitrogen isotope values of the Sakhtysh IIa humans against the background of isotope ranges of animals from Zvejnieki, Latvia (light-shaded boxes) depicted together with the ranges of their consumers (dark-shaded boxes) after a standard trophic level shift of 1\%o for ${ }^{13} \mathrm{C}$ and $3.5 \%$ for $\delta^{15} \mathrm{~N}$. Isotope ranges of brown bear and otter are depicted separately (red frames) (Zvejnieki isotope ranges: after Eriksson 2006). 
Fig. 17. Carbon and nitrogen isotope values of the Sakhtysh IIa humans and humans from Zvejnieki, Latvia, against the background of isotope ranges of animals from Zvejnieki (light-shaded boxes) depicted together with the ranges of their consumers (dark-shaded boxes) after a standard trophic level shift of 1\%o for $\delta^{13} \mathrm{C}$ and $3.5 \%$ for ${ }^{15} \mathrm{~N}$. Isotope ranges of brown bear and otter are depicted separately (red frames) (Zvejnieki isotopic ranges and values: after Eriksson 2006).

Fig. 18. Carbon and nitrogen isotope values of the Sakhtysh IIa humans against the background of isotope ranges of animals from Denmark (light-shaded boxes) depicted together with the ranges of their consumers (dark-shaded boxes) after a standard trophic level shift of 1\%o for $813 \mathrm{C}$ and $3.5 \%$ for $\delta^{15} \mathrm{~N}$ (Danish faunal isotopic ranges: after Fischer et al. 2007).
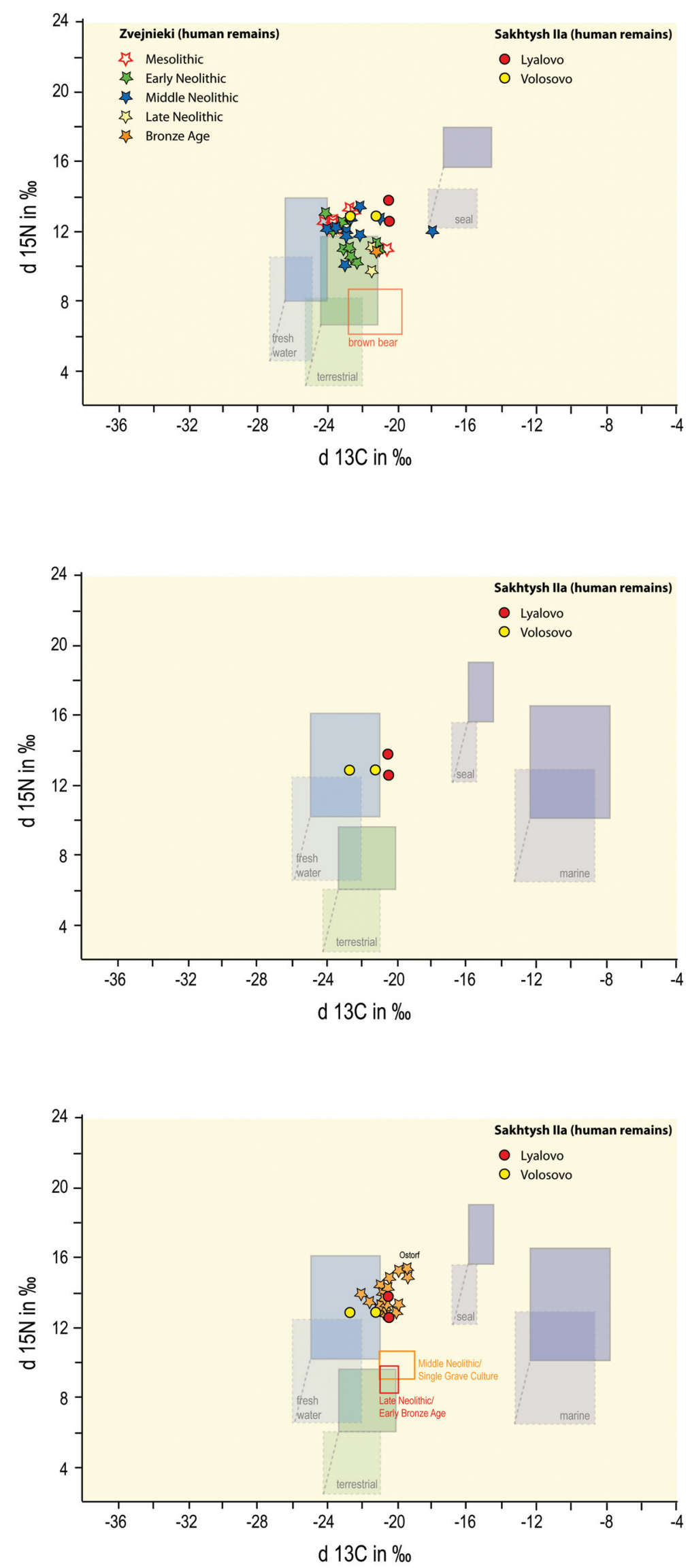

d $13 \mathrm{C}$ in $\%$
Fig. 19. Carbon and nitrogen isotope values of the Sakhtysh IIa humans and humans from Ostorf, Germany (orange stars) and isotope ranges of Middle Neolithic (orange frame) and Late Neolithic/Bronze Age (red frame) human remains from German sites, against the background of isotope ranges of animals from Denmark (light-shaded boxes) depicted together with the ranges of their consumers (dark-shaded boxes) after a standard trophic level shift of $1 \%$ for $813 \mathrm{C}$ and $3.5 \%$ for $815 \mathrm{~N}$ (Ostorf human isotope values: after Olsen, Heinemeier 2007; German Neolithic and Bronze Age isotope ranges: unpublished, publication by Terberger et al. in preparation; $\mathrm{Da}$ nish faunal isotope ranges: after Fischer et al. 2007). 


\section{References}

Andersen G. J., Heinemeier J., Nielsen H. L., Thomsen M. S., Johnsen S., Sveinsbjörnsdóttir A. E. and Hjartarson A. 1989. AMS ${ }^{14} \mathrm{C}$ dating on the Fossfogur sediments, Iceland. Radiocarbon 31: 592-600.

Bonsall C., Cook G. T., Hedges R. E. M., Higham T. F. G., Pickard C. and Radovanović I. 2004. Radiocarbon and stable isotope evidence of dietary change from the Mesolithic to the Middle Ages in the Iron Gates: New results from Lepenski Vir. Radiocarbon 46(1): 293-300.

DeNiro M. J. 1985. Postmortem preservation and alteration of in vivo bone collagen isotope ratios in relation to paleodietary reconstruction. Nature 317: 806-809.

DeNiro M. J., Epstein S. 1981. Influence of diet on the distribution of nitrogen isotopes in animals. Geochimica et Cosmochimica Acta 45: 341-351.

Engovatova A. V. 1998. Khronologiya epokhi neolita Volgo-Okskogo mezhdurech'ya [The chronology of the Neolithic of the Volga-Oka interfluve]. Tverskoi Arkheologicheskii Sbornik 3: 238-246. (in Russian)

Engovatova A. V., Zhilin M. G. and Spiridonova E. A. 1998. Khronologiya verkhnevolzhskoi ranneneoliticheskoi kultury (po materialam mnogosloinykh pamyatnikov VolgoOkskogo mezhdurechya) [The chronology of the Upper Volga Early Neolithic culture (according to materials from multilayered sites between the Volga and Oka rivers)]. Rossiiskaya Arkheologiya 2: 11-21. (in Russian)

Eriksson G. 2006. Stable isotope analysis of human and faunal remains from Zvejnieki. In L. Larsson, I. Zagorska (eds.), Back to the Origin. New research in the Mesolithic-Neolithic Zvejnieki cemetery and environment, northern Latvia. Almqvist \& Wiksell International. Lund: 183-215. (in Russian)

Fischer A., Olsen J., Richards M., Sveinbjörnsdóttir Á. E. and Bennike P. 2007. Coast-inland mobility and diet in the Danish Mesolithic and Neolithic - evidence from stable isotope values of humans and dogs. Journal of Archaeological Science 34: 2125-2150.

Grünberg J. M. 2000. Mesolithische Bestattungen in Europa. Ein Beitrag zur vergleichenden Gräberkunde. Internationale Archäologie 40. Verlag Marie Leidorf. Rahden/Westf.

Gurina N. N., Krainov D. A. 1996. Lyalovskaya kultura (The Lyalovo culture). In S. V. Oshibkina (ed.), Neolit Severnoi Evrazii. Nauka. Moskva: 173-182. (in Russian)

Jacobi R. M., Higham T. F. G. and Lord T. C. 2009. Improving the chronology of human occupation of Britain dur- ing the Late Glacial. In M. Street, N. Barton and T. Terberger (eds.), Humans Environment and Chronology of the Late Glacial of the North European Plain. RGZM-Tagungen 6. Verlag Römisch-Germanisches Zentralmuseum. Mainz: 7-25.

Jørkov M. L. S., Heinemeier J. and Lynnerup N. 2007. Evaluating bone collagen extraction methods for stable isotope analysis in dietary studies. Journal of Archaeological Science 34: 1824-1829.

Kashina E. A. 2004. Antropomorfnye izobrazheniya iz gliny v neolite-eneolite lesnoi zony Vostochnoi Evropy (Anthropomorphic clay images in the Neolithic and Eneolithic of the forest zone of Eastern Europe). Rossiiskaya arkheologiya 3: 20-32. (in Russian)

Kostyleva E. L., Utkin A. V. 2008a. Khronologiya pogrebal'nogo obryada volosovskoi kul'tury territorii Verkhnego Povolzh'ya I Volga-Okskogo mezhdurech'ya (The chronology of the burial customs of the Volosovo culture on the Upper Volga and Volga-Oka territories). In A. P. Derevyanko, N. A. Makarov (eds.), Trudy II (XVIII) Vserossiiskogo Arkheologicheskogo S'ezda v Suzdale. Institut Arkheologii RAN. Moskva: 230-233. (in Russian)

2008b. Pogrebal'nye kompleksy epokhi pervobytnosti na Sakhtyshskom torfyanike (Burial complexes of the prehistoric period in the Sakhtysh peat bog). Vestnik Ivanovskogo gosudarstvennogo universiteta, seriya 'Gumanitarnye nauki' 4: 3-20. (in Russian)

2010. Neo-eneoliticheskie mogil'niki Verkhnego Povolzh'ya $i$ Volga-Okskogo Mezhdurech'ya: Planigraficheskie I khronologicheskie struktury (The Neolithic and Aeneolithic burials of the Upper Volga region and the Volga-Oka interfluve: Planigraphic and chronological structures). TAUS. Moskva. (in Russian)

2012. Stadialnost i struktura lyalovskogo pogrebalnogo obryada na territorii verkhnego Povolzhya I VolgaOchya (Stages and structure of the Lyalovo burial custom in the Upper Volga and the Volga-Oka region). In S. A. Vasiliev, V. Ya. Shumkin (eds.), Mezolit $i$ neolit Vostochnoi Evropy: Khronologiya i kulturnoe vzaimodeistvie. IIMK RAN/MAE RAN. St. Peterburg: 232240. (in Russian)

Krainov D. A. 1996. Verkhnevolzhskaya kultura (Upper Volga culture). In S. V. Oshibkina (ed.), Neolit Severnoi Evrazii. Nauka. Moskva: 166-173. (in Russian)

Larsson L., Zagorska I. (eds.) 2006. Back to the Origin. New research in the Mesolithic-Neolithic Zvejnieki cemetery and environment, northern Latvia. Almqvist \& Wiksell International. Lund. 
Lillie M. C., Budd C. E. and Potekhina I. D. 2011. Stable isotope analysis of prehistoric populations from the cemeteries of the Middle and Lower Dnieper Basin, Ukraine. Journal of Archaeological Science 38(1): 57-68.

Lübke H., Lüth F. and Terberger T. 2007. Fishers or Farmers? The archaeology of the Ostorf cemetery and related Neolithic finds in the light of new data. In L. Larsson, F. Lüth and T. Terberger (eds.), Innovation and Continuity - Non-Megalithic Mortuary Practices in the Baltic. New Methods and Research into the Development of Stone Age Society. International Workshop at Schwerin on 2426 March 2006. Bericht der Römisch-Germanischen Kommission 88. Philipp von Zabern. Mainz am Rhein: 307-338.

Nunez M. 1986. Clay figurines from the Aland islands and mainland Finland. Fennoscandia archaeologica 3: 17-34.

Olsen J., Heinemeier J. 2007. AMS dating of human bone from the Ostorf cemetery in the light of new information on dietary habits and freshwater reservoir effects. In L. Larsson, F. Lüth and T. Terberger (eds.), Innovation and Continuity - Non-Megalithic Mortuary Practices in the Baltic. New Methods and Research into the Development of Stone Age Society. International Workshop at Schwerin on 24-26 March 2006. Bericht der Römisch-Germanischen Kommission 88. Verlag Philipp von Zabern. Mainz: 339-352.

Olsen J., Heinemeier J., Lüth F., Lübke H. and Terberger T. 2010. Dietary habits and freshwater reservoir effects in bones from a Neolithic NE German cemetery. Radiocarbon 52(2): 635-644.

Oshibkina S. V. 2006. K voprosu o neoliticheskoi revolyuciiv v lesnoi zone Evrasii (On the question of the Neolithic revolution in the forest zone of Eurasia). In II Northern Archaeological Congress, 24-30 September 2006, Khanty-Mansiisk. Papers. IzdatNaukaServis, Ekaterinburg, Khanty-Mansiisk: 262-279. (in Russian)

2007. Mogilniki i pogrebalnye kompleksy epokhi mezolita v lesnoi zone Vostochnoi Evropy (Cemeteries and burial complexes of the Mesolithic in the forest zone of Eastern Europe). Rossiiskaya arkheologiya 1: 36-48. (in Russian)
Petrova N. Yu. 2008. Prirodnaya adaptaciya goncharnogo proizvodstva drevnikh volosovcev (Environmental adaptation of the pottery production of the ancient Volosovo people). In A. P. Derevyanko, N. A. Makarov (eds.), Trudy II (XVIII) Vserossiiskogo Arkheologicheskogo S'ezda v Suzdale. Institut Arkheologii RAN. Moskva: 259261. (in Russian)

Reimer P. J. and 28 authors 2009. IntCal09 and Marine09 radiocarbon age calibration curves, 0-50,000 years cal BP. Radiocarbon 51(4): 1111-1150.

Stuiver M., Polach H. A. 1977. Discussion: reporting of ${ }^{14} \mathrm{C}$ data. Radiocarbon 19(3): 355-363.

Terberger T. 2010. Die Alt- und Mittelsteinzeit (1,3 Millionen Jahre - $4000 \mathrm{v}$. Chr.). In S. von Schnurbein (ed.), Atlas der Vorgeschichte. Europa von den ersten Menschen bis Christi Geburt. Konrad Theiss Verlag, Stuttgart: 1057.

van Klinken G. J. 1999. Bone collagen quality indicators for palaeodietary and radiocarbon measurements. Journal of Archaeological Science 26: 687-695.

Wood R. E., Higham T. F. G, Buzilhova A., Suvorov A., Heinemeier J. and Olsen J. 2013. Freshwater radiocarbon reservoir effects at the burial ground of Minino, Northwest Russia. Radiocarbon 55(1): 163-177.

Zaretskaya N. E., Kostyleva E. L. 2008. Radiouglerodnaya khronologiya nachal'nogo etapa verkhnevolzhskoi panneneoliticheskoi kul'tury (Radiocarbon chronology of the initial phase of the Upper Volga archaeological culture). Rossiiskaya arkheologiya 1: 5-14. (in Russian)

2010. Novye dannye po absolyutnoi khronologii Lyalovskoi kultury (New data on the absolute chronology of the Lyalovo culture). Tverskoi Arkheologicheskii Sbornik 8: 175-83. (in Russian)

Zhilin M. G. 2006. Das Mesolithikum im Gebiet zwischen den Flüssen Wolga und Oka: einige Forschungsergebnisse der letzten Jahre. Pähistorische Zeitschrift 81: 1-48. 